Article

\title{
Quantitative Estimation of the Velocity of Urbanization in China Using Nighttime Luminosity Data
}

\author{
Ting Ma ${ }^{1,2, *}$, Zhan Yin ${ }^{1,3}$, Baolin Li ${ }^{1}$, Chenghu Zhou ${ }^{1}$ and Susan Haynie ${ }^{4}$ \\ 1 State Key Laboratory of Resources and Environmental Information System, Institute of Geographical \\ Sciences and Natural Resources Research, Chinese Academy of Sciences, Beijing 100101, China; \\ yinz@lreis.ac.cn (Z.Y.); libl@lreis.ac.cn (B.L.); zhouch@lreis.ac.cn (C.Z.) \\ 2 Jiangsu Center for Collaborative Innovation in Geographical Information Resource \\ Development and Application, Nanjing 210023, China \\ 3 University of Chinese Academy of Sciences, Beijing 100049, China \\ 4 Demographic Consulting, Inc., Santa Ana, CA 92706, USA; shaynie@geodemo.com \\ * Correspondence: mting@1reis.ac.cn; Tel.: +86-10-6488-9630
}

Academic Editors: Yuhong He, Qihao Weng, Ioannis Gitas and Prasad S. Thenkabail Received: 9 November 2015; Accepted: 18 January 2016; Published: 26 January 2016

\begin{abstract}
Rapid urbanization with sizeable enhancements of urban population and built-up land in China creates challenging planning and management issues due to the complexity of both the urban development and the socioeconomic drivers of environmental change. Improved understanding of spatio-temporal characteristics of urbanization processes are increasingly important for investigating urban expansion and environmental responses to corresponding socioeconomic and landscape dynamics. In this study, we present an artificial luminosity-derived index of the velocity of urbanization, defined as the ratio of temporal trend and spatial gradient of mean annual stable nighttime brightness, to estimate the pace of urbanization and consequent changes in land cover in China for the period of 2000-2010. Using the Defense Meteorological Satellite Program-derived time series of nighttime light data and corresponding satellite-based land cover maps, our results show that the geometric mean velocity of urban dispersal at the country level was $0.21 \mathrm{~km} \cdot \mathrm{yr}^{-1}$ across $88.58 \times 10^{3} \mathrm{~km}^{2}$ urbanizing areas, in which $\sim 23 \%$ of areas originally made of natural and cultivated lands were converted to artificial surfaces between 2000 and 2010. The speed of urbanization varies among urban agglomerations and cities with different development stages and urban forms. Particularly, the Yangtze River Delta conurbation shows the fastest $\left(0.39 \mathrm{~km} \cdot \mathrm{yr}^{-1}\right)$ and most extensive $\left(16.12 \times 10^{3} \mathrm{~km}^{2}\right)$ urban growth in China over the 10-year period. Moreover, if the current velocity holds, our estimates suggest that an additional $13.29 \times 10^{3} \mathrm{~km}^{2}$ in land area will be converted to human-built features while high density socioeconomic activities across the current urbanizing regions and urbanized areas will greatly increase from $52.44 \times 10^{3} \mathrm{~km}^{2}$ in 2010 to $62.73 \times 10^{3} \mathrm{~km}^{2}$ in China's mainland during the next several decades. Our findings may provide potential insights into the pace of urbanization in China, its impacts on land changes, and accompanying alterations in environment and ecosystems in a spatially and temporally explicit manner.
\end{abstract}

Keywords: urbanization; velocity; nighttime lights; land use change; China

\section{Introduction}

As the nation's economy continues to grow, China is experiencing a historically unprecedented scale and pace of urbanization. Between 2000 and 2010, the percent of the population residing in cities dramatically increased from $36.2 \%$ ( 0.46 billion) to $50.1 \%$ ( 0.66 billion) [1,2]. Based on the 
current trend, the proportion of urban population is projected to be $\sim 76 \%$ by 2050 , and 0.3 billion more people will likely be added to China's urban areas in the next several decades [3]. Meanwhile, continuous rural-urban migration and urban expansion will drive the emergence of more megacities, large cities and new cities [3]. Rapid urbanization usually leads to incremental changes and shifts in environmental systems resulting from the rising demands of infrastructure construction, material production, appropriation and consumption due to escalated human social and economic activities [4]. In the context of sustainable development and political decision-making, improved understanding of the pace of urbanization across geographical ranges is therefore of crucial importance for spatially tracking urban growth, land change, environmental shift and ecological responses to the propagation of urban-related activities (i.e., population, socioeconomic status, buildings and infrastructures) [5-7]. Despite its importance, the spatial rate of urban growth in China has until now been much less investigated, mainly owing to the limited capability of statistical data and land use maps for estimating spatio-temporal dynamics of urban activities and the complexity of urbanization processes [8,9].

Satellite-derived observations of anthropogenic brightness at night have been universally regarded as effective proxy measures of urban dynamics due to significant quantitative relationships between nighttime lighting signals and demographic and socioeconomic variables in relation to urbanization processes at local, regional and national scales [10-13]. In comparison with statistical data and land use maps, continuous surveys of nighttime lights can provide consistent and spatially explicit information regarding human activities and urban development [14-16]. Most previous works were dedicated to studying quantitative responses of artificial nighttime radiances to corresponding socioeconomic variables within given administrative units and obtaining general estimates for urbanization patterns and trends. The spatio-temporal spreads of nighttime lights, while closely related to the expansions of high density human settlements and crucial for expanding our understanding of urbanization processes, have received much less attention. Recent efforts suggest that long-term observations of spatial distributions and fluctuations in artificial nighttime radiances could enable us to track the pace of urbanization in a spatially and temporally explicit manner [17-19]. Hence, the primary objective of this paper is to develop a nighttime light-based index of the velocity of urbanization. This quantitative index is derived from the pixel-level ratio of temporal trend and spatial gradient of mean annual stable nighttime radiances. We use the index of the velocity of urbanization to estimate the spatial propagation rate of high density demographic and socioeconomic activities during the rapid and remarkable urbanization process in China and its impacts on land use change for the period of 2000-2010. In this study, we investigate the velocity of urbanization and subsequent land use change at three different levels: country, conurbation and city, in order to obtain understanding of multi-scale urbanization processes in China. Moreover, velocity-based predictions of urban growth are carried out for extra-large and large cities to demonstrate the potential application of the index of velocity in urbanization studies.

\section{Materials and Methods}

\subsection{Nighttime Luminosity Data}

Annual cloud-free composited stable nighttime light (NTL) imagery obtained by the Defense Meteorological Satellite Program (DMSP) [20] was used to investigate the urban growth in China from 2000 to 2010. DMSP data consist of $30 \times 30$ arc-seconds (approximately $1 \times 1 \mathrm{~km}$ at the equator) gridded cell-based nocturnal luminosity ranging from 0 to 63 . DMSP nighttime light imagery spanning 1994-2013 were separately collected by five sensors: F12 (1994-1999), F14 (2000-2003), F15 (2000-2007), F16 (2004-2009) and F18 (2010-2013). To improve the accuracy and precision of our urbanization assessment, we performed the following operations: First, to reduce inter-annual variations and response variations among different sensors, we employed a second-order regression method to inter-calibrate DMSP data with respect to the 1999 F12 composite (according to Elvidge et al. [21,22]). The annual composites which showed the best fitting regression 
in inter-calibration were then assembled into a time series of nighttime light data for subsequent analyses. Second, maximum correlation analyses were employed to detect the pixel shift between different images for inter-correcting geo-location biases of DMSP data [23]. A sample region (spatially ranged from $51.61 \mathrm{~N}$ to $51.73 \mathrm{~N}$ and from $124.29 \mathrm{E}$ to $124.48 \mathrm{E}$ ) covering Xinlin City, with no conspicuous increases in urban extent and population over the past decade according to land use maps and population census data, was chosen to obtain estimates for relative shifts of pixels to match the 1999 F12 image to maintain consistency with the inter-calibration of radiance [22]. All target DMSP images were geo-corrected based upon the estimated relative pixel shifts. Third, MODIS (Moderate Resolution Imaging Spectroradiometer) derived monthly average normalized difference vegetation indices (NDVI) (July through September) were applied to adjust corresponding nighttime light values through calculating $(1-N D V I) \times$ NTL at the pixel level to reduce the saturation effect and to enhance inter-urban variability of DMSP nighttime light radiances [24]. Finally, we used a locally weighted scatter plot smoothing algorithm [25] to further eliminate inter-annual fluctuations and noise within the NTL time series at the pixel level to obtain clearer trends in long-term observations of artificial nighttime lights.

\subsection{The Calculation of the Velocity of Urbanization}

Closely akin to the index of instantaneous horizontal velocity of temperature change proposed by Loarie et al. [26], the nighttime light-derived velocity of urbanization $V_{\text {urban }}\left(\mathrm{km} \cdot \mathrm{yr}^{-1}\right)$ is defined as the ratio of the rate of nighttime luminosity through time $T_{\text {trend }}\left(\mathrm{NTL} \cdot \mathrm{yr}^{-1}\right)$ and the spatial gradient of mean annual stable nighttime light at that location $G_{\text {spatial }}\left(\mathrm{NTL} \cdot \mathrm{km}^{-1}\right)$ :

$$
V_{\text {urban }}=\frac{T_{\text {trend }}}{G_{\text {spatial }}}
$$

We used a linear regression model to calculate the temporal trend in the time series of nighttime light $T_{\text {trend }}$ from 2000 to 2010:

$$
N T L_{t}=\text { Intercept }+T_{\text {trend }} \times t(t=2000, \cdots, 2010)
$$

where NTL $L_{t}$ stands for the NTL value in year $t$. Linear least-squares estimation was used to estimate $T_{\text {trend }}$ with a two-tailed $t$-test for statistical significance testing:

$$
T_{\text {trend }}=\frac{\sum_{t=2000}^{2010}\left(t-t_{\text {ave }}\right)\left(N T L_{t}-N T L_{\text {ave }}\right)}{\sum_{t=2000}^{2010}\left(t-t_{\text {ave }}\right)^{2}}
$$

where $N T L_{\text {ave }}$ and $t_{\text {ave }}$ are the mean value of the NTL series and year, respectively. As illustrated in Figure 1, spatial gradients of nighttime light $G_{\text {spatial }}$ were estimated from the map of mean annual DSMP radiance data using the average maximum technique (typically used in the calculation of terrain slope and aspect [27]) based on a $3 \times 3$ grid cell neighborhood:

$$
\begin{gathered}
G_{\text {spatial }}=\sqrt{[d N T L / d x]^{2}+[d N T L / d y]^{2}} \\
{[d N T L / d x]=\left[\left(N T L_{2}+2 N T L_{5}+N T L_{8}\right)-\left(N T L_{0}+2 N T L_{3}+N T L_{6}\right)\right] /(8 \times x \text { size })} \\
{[d N T L / d y]=\left[\left(N T L_{6}+2 N T L_{7}+N T L_{8}\right)-\left(N T L_{0}+2 N T L_{1}+N T L_{2}\right)\right] /(8 \times y \text { size })}
\end{gathered}
$$

The velocity of urbanization, at which rising artificial nighttime radiances closely related to intensifying demographic and socioeconomic activities tend to diffuse in geographical space, yields quantitative estimates for both the spatial rate and direction of urban activity displacement. To decrease the incidence of minor and infinite speeds, caused by slight temporal trends and spatial gradients, 
respectively, only grid cells with significant positive trend $(p>0.05)$ and conspicuous spatial gradient $(\geqslant 1$ digital number) were taken into account. In addition, to reduce the effects of distortions in distance and area under the WGS84 geographic coordinate reference system, we applied the great circle distance and the ellipsoid trapezoid area to calculate the size and the area of DMSP pixels, respectively.

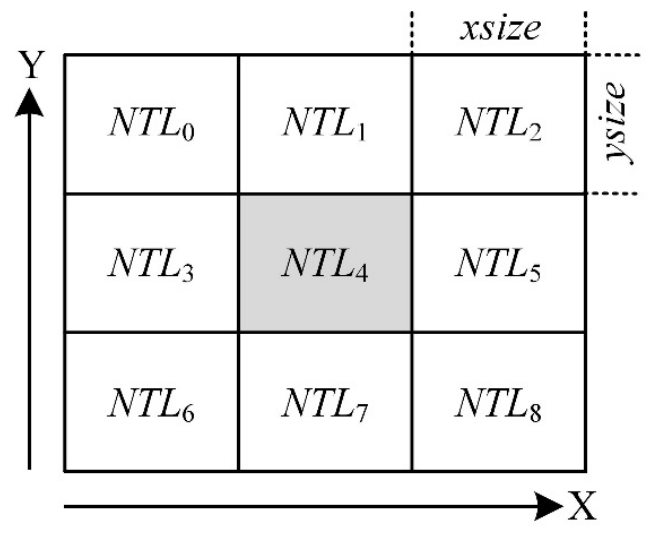

Figure 1. Schematic diagram of the calculation of the spatial gradients of nighttime light.

\subsection{Land Use and Socioeconomic Data}

Land cover data of China (named ChinaCover) were used to investigate the responses of land use dynamics to synchronously increasing urban activities. The primary objective of the ChinaCover land use product is to facilitate understanding of anthropogenic land use changes and environmental consequences in China between 2000 and 2010 [28]. ChinaCover data were produced from $30 \mathrm{~m}$ Landsat imagery (for 2000) and $30 \mathrm{~m} \mathrm{HJ}-1$ data (for 2010), respectively, through the association of knowledge-based visual interpretation and object-oriented automatic classification technology [28]. The classification scheme of ChinaCover includes six classes and 39 subclasses of lands: 13 subclasses of forest and shrub lands, four subclasses of grass lands, seven subclasses of wet lands, two subclasses of croplands, four subclasses of artificial lands and nine subclasses of desert and bare lands. Classification results and accuracy have been verified by field investigations [28].

Gridded population data and a density map of POIs (points of interest, mainly consisting of residential areas, restaurants, hotels, traffic stations, entertainment, public utilities and commercial service sites) with spatial resolution of $30 \times 30$ arc-seconds were used to identify nighttime lighting areas with conspicuous human activity. A population map was produced from population census data in 2010 by a dasymetric mapping method in which county-level census counts were disaggregated to gridded cells according to probability coefficients, jointly estimated from terrain, land cover, road proximity and residential areas which may have distinct influences on the distribution of ambient population (detailed descriptions and explanations regarding the method can be found in Dobson et al. [29]). For generating the gridded density map of POIs, we first counted the number of POIs contained within each gridded cell. Second, we used Gaussian kernel to locally smooth the density of POI counts assuming spatial continuity in human activities. Based upon these two gridded maps, DMSP nighttime light pixels in which no POIs or population have been identified were excluded from subsequent analysis.

\section{Results and Discussions}

\subsection{Spatial Features of the Velocity Map of Urbanization}

As exemplified by cities in the Yangtze River Delta (Figure 2), mapping the velocity of urbanization allows us to portray the spatio-temporal evolution and pattern of urban expansion through measuring the dispersal of artificial nighttime light signals. As demonstrated in Figure $2 \mathrm{c}, \mathrm{d}$, rapid increases 
in nighttime lights generally occurred in the initial peri-urban and urban-rural transition zones which gradually evolved to developed areas with continuously enhanced socioeconomic activities. Conversely, no significant velocity was detected in the original central urban areas which typically showed consistently high nighttime light radiances and flat spatial gradients. Thus, using the velocity map of urbanization, we could spatially partition a given city region into two different types according to nighttime light dynamics: (1) urbanizing areas with significantly enhanced artificial radiances since 2000 and (2) urbanized areas with relatively high and stable nocturnal brightness, generally being local central areas and those closely connected to high density population and human-built features in comparison to contiguous urbanizing areas (Figure 2e). Moreover, the geographical distribution of nighttime lights typically reveals a radial outward movement of relatively intensive urban activities, with gradual spatial dispersal and emergence of artificial surfaces geographically along the center-to-periphery gradient (Figure 2e). The index of the velocity of urbanization therefore enables us to investigate how fast urban activities expanded in geographical space, with concurrent land use change (Figure 2f).
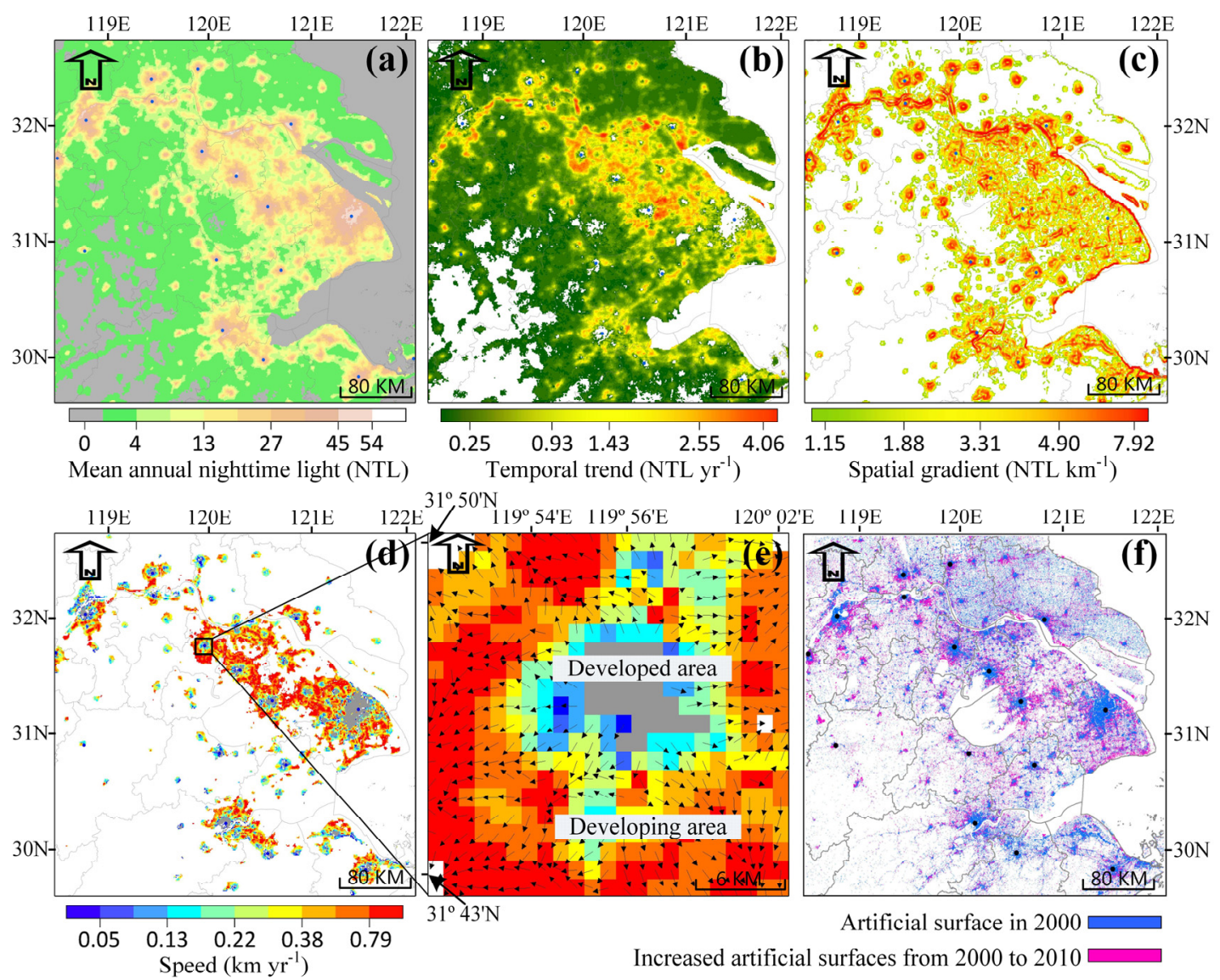

Figure 2. Illustrations of the index of the velocity of urbanization for cities in the Yangtze River Delta. Solid dots represent the local centers of cities. (a) Mean annual nighttime stable lights for the period of 2000-2010; (b) long-term linear trends in nighttime lights; (c) the spatial gradient of mean annual nighttime lights; (d) the velocity of nighttime light change; (e) the speed and direction of nighttime light change for Changzhou City, in which the central gray region indicates the developed area surrounded by developing areas and (f) artificial surface change between 2000 and 2010.

\subsection{The Velocity of Urbanization for China's Urban Areas}

Nationwide estimates reveal that marked dispersals of urban activities have occurred on $88.58 \times 10^{3} \mathrm{~km}^{2}$ of land surface with a geometric mean velocity of $0.21 \mathrm{~km} \cdot \mathrm{yr}^{-1}$ around 
$20.53 \times 10^{3} \mathrm{~km}^{2}$ developed areas. (The geometric mean is used throughout due to skewed distributions of the velocity.) Figure 3 shows the distribution of the velocity of urbanization by land area of major and smaller cities. Fifty-nine percent of land area was within 251 major cities (defined as having at least 0.2 million inhabitants inside the city's administrative districts in 2010 and having a significant velocity of urbanization). Major cities have an above-average velocity of urbanization with a mean speed of $0.22 \mathrm{~km} \cdot \mathrm{yr}^{-1}$. Around $14.97 \times 10^{3} \mathrm{~km}^{2}$ of urbanized area was within those major cities. Comparatively, even though starting from only $5.56 \times 10^{3} \mathrm{~km}^{2}$ in built-up area, small cities, new cities and towns in total account for a considerable proportion (41\%) of urbanizing areas with a corresponding mean velocity of $0.19 \mathrm{~km} \cdot \mathrm{yr}^{-1}$. The proportion of China's urban population in small cities and towns increased markedly from 16\% in 2000 to 30\% in 2010 [1,2], most likely resulting from locally rising rural-urban migration promoted by institutional changes and small-town construction. These results imply a significant urban growth in small cities and towns comparable to that in larger cities over the past decade in China.

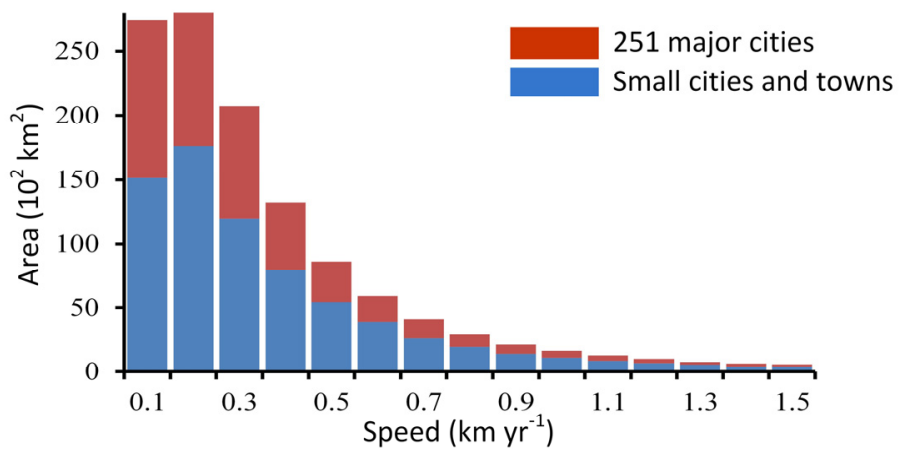

Figure 3. Land area distributions by speed of urbanization for China's urban areas having a significant velocity of urbanization.

\subsection{The Velocity of Urbanization in Urban Agglomerations and Cities}

Urban agglomeration, generally linked to the term of conurbation, is defined as a large urban cluster where the urban areas of distinct cities are spatially connected by continuous built-up development. Urban agglomeration plays a crucial role in China's urbanization due to the increasing importance of both regional development and environmental impacts [30]. Our estimates show various magnitudes and velocities of urbanization among the 10 largest conurbations from 2000 to 2010 (Figure 4). The largest and fastest growing urban regions appeared in the Yangtze River.

Delta conurbation has a high velocity of $0.39 \mathrm{~km} \cdot \mathrm{yr}^{-1}$ on $16.63 \times 10^{3} \mathrm{~km}^{2}$ of land. Urban agglomerations in Jing-Jin-Ji and the Pearl River Delta also exhibit sizeable urbanization dispersals: over $9.26 \times 10^{3} \mathrm{~km}^{2}$ with $0.17 \mathrm{~km} \cdot \mathrm{yr}^{-1}$ and $7.88 \times 10^{3} \mathrm{~km}^{2}$ with $0.22 \mathrm{~km} \cdot \mathrm{yr}^{-1}$, respectively. Moreover, although the urbanizing areas are similar, the urbanization velocities in western urban agglomerations, including Central Shaanxi Plain $\left(0.23 \mathrm{~km} \cdot \mathrm{yr}^{-1}\right)$ and Sichuan-Chongqing $\left(0.27 \mathrm{~km} \cdot \mathrm{yr}^{-1}\right)$, are conspicuously higher than in central urban agglomerations (Central Plains and Middle Reaches of Yangtze River, $0.19 \mathrm{~km} \cdot \mathrm{yr}^{-1}$ and $0.17 \mathrm{~km} \cdot \mathrm{yr}^{-1}$, respectively), and two eastern urban agglomerations (Liaodong Peninsula and Shandong Peninsula, $0.15 \mathrm{~km} \cdot \mathrm{yr}^{-1}$ and $0.18 \mathrm{~km} \cdot \mathrm{yr}^{-1}$, respectively), driven by the performance of the western region development strategy since 2001 [31].

Estimations at the city level suggest that China's major cities varied in speed of urbanization and growth in urbanizing areas from 2000 to 2010 (Figure 5). The high mean speed of urbanization has been found in Changzhou $\left(0.69 \mathrm{~km} \cdot \mathrm{yr}^{-1}\right)$, Wuxin $\left(0.64 \mathrm{~km} \cdot \mathrm{yr}^{-1}\right)$ and Suzhou $\left(0.63 \mathrm{~km} \cdot \mathrm{yr}^{-1}\right)$, with relatively moderate urbanizing area: $0.74 \times 10^{3} \mathrm{~km}^{2}, 0.81 \times 10^{3} \mathrm{~km}^{2}$ and $0.93 \times 10^{3} \mathrm{~km}^{2}$, respectively. The fact that these three cities are located within the Yangtze River Delta further indicates that this region had the fastest urbanization process in China from 2000 to 2010, and was a component of that regional process. Comparatively, although having a similar urbanizing area and larger current 
urban population than in the Yangtze River Delta (except Shanghai), cities in the Pearl River Delta (for instance, Shenzhen and Dongguan, with speeds of $0.12 \mathrm{~km} \cdot \mathrm{yr}^{-1}$ and $0.17 \mathrm{~km} \cdot \mathrm{yr}^{-1}$, respectively) typically show a lower velocity of urbanization over the past decade. This result could indicate that notable urbanization processes have occurred before 2000 in the Pearl River Delta region. Moreover, megacities, including Beijing $\left(0.20 \mathrm{~km} \cdot \mathrm{yr}^{-1}\right)$, Shanghai $\left(0.43 \mathrm{~km} \cdot \mathrm{yr}^{-1}\right)$, Guangzhou $\left(0.28 \mathrm{~km} \cdot \mathrm{yr}^{-1}\right)$ and Tianjin $\left(0.25 \mathrm{~km} \cdot \mathrm{yr}^{-1}\right)$ generally show medium velocities but with larger urbanizing land area: $2.11 \times 10^{3} \mathrm{~km}^{2}, 2.92 \times 10^{3} \mathrm{~km}^{2}, 1.55 \times 10^{3} \mathrm{~km}^{2}$ and $1.76 \times 10^{3} \mathrm{~km}^{2}$, respectively. This implies continuous and consistent urban growth in China's extra-large cities.

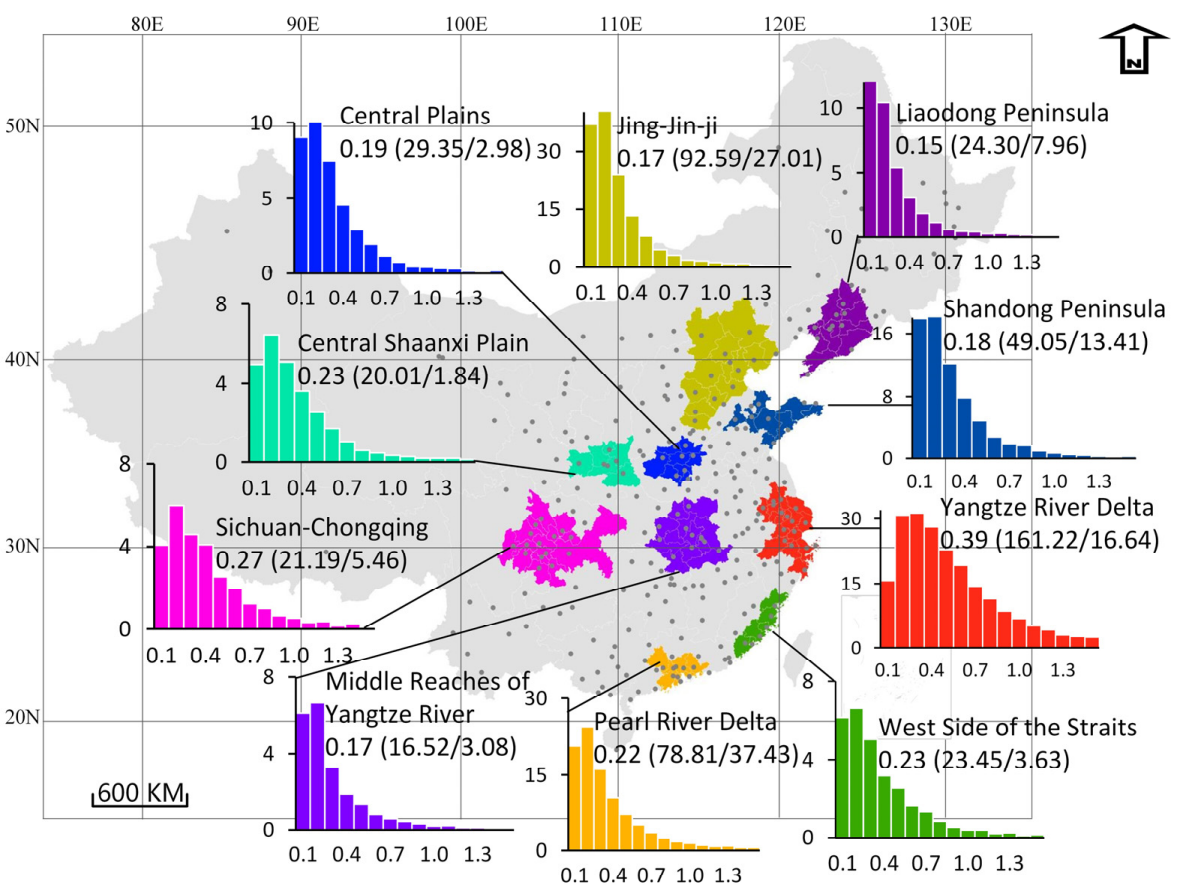

Figure 4. Distribution of land area by speed of urbanization for the 10 largest urban agglomerations in China. Grey dots indicate the geographical locations of major cities. Labels display mean speed in $\mathrm{km} \cdot \mathrm{yr}^{-1}$ (urbanizing land area/urbanized land area, in $10^{2} \mathrm{~km}^{2}$ ). The $\mathrm{x}$-axis and $\mathrm{y}$-axis of histogram stand for speed $\left(\mathrm{km} \cdot \mathrm{yr}^{-1}\right)$ and land area $\left(10^{2} \mathrm{~km}^{2}\right)$, respectively.

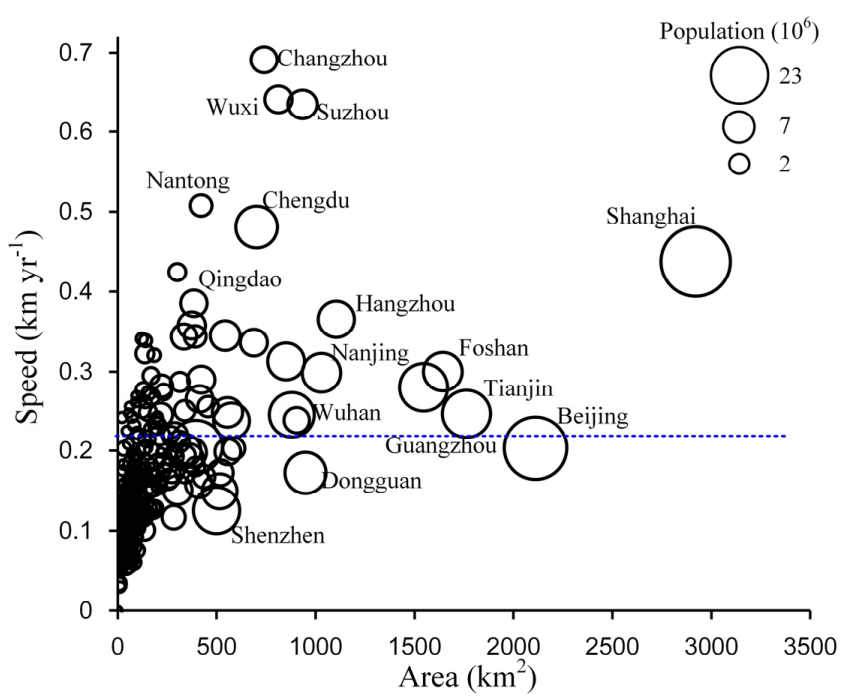

Figure 5. The mean speed of urbanization versus urbanizing land area for 251 Chinese major cities. The blue dotted line indicates the geometric mean value of the urbanization velocity at the national level. 


\subsection{Land Use Changes during Urbanization}

During urban expansion, increases in artificial surfaces and changes in land use patterns could bring a wide array of environmental problems and impose a considerable challenge for the conservation of resources and sustainable development [5,7]. Associating the map of velocity of urbanization with $30 \mathrm{~m}$ resolution land cover images, we investigated the response of land use and land cover dynamics to simultaneous urban growth between 2000 and 2010 in China. As mentioned above, every DMSP pixel covers approximately 900 ChinaCover pixels. Thus, we can examine the conversion proportion of land cover to artificial surfaces for a given DMSP pixel with estimated urbanization speed. Figure 6 shows the significant positive linear relationship (with a two-tailed $t$-test, $p<0.001$ ) between the proportion of land cover converted to artificial surfaces and the mean speed of urbanization for vigintiles of the velocity summarized from pixel level within China's cities. This result suggests that faster dispersal of urban activities might lead to greater land use conversion to urban impervious surfaces.

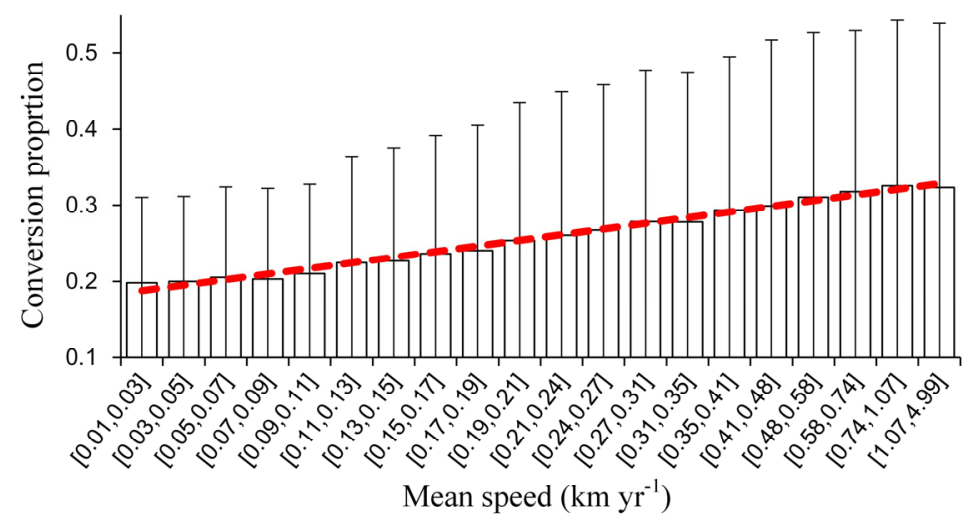

Figure 6. The pixel-level relationship between the conversion proportion of land cover to artificial surfaces and the median of individual vigintiles of the speed of urbanization. One vigintile means $5 \%$ of all pixels. The 25 th-75th percentile for individual vigintiles are presented in boxplots. The red dashed line represents the linear fit.

Circular plots (shown in Figure 7, referring to Abel and Sander, [32]) illustrate different types of land use conversions for urbanizing areas identified as having conspicuously growing and spreading urban activities over the past decade based on the velocity of urbanization. In all urbanizing lands of China's cities and towns (Figure 7a), artificial surfaces have grown greatly from $32.32 \times 10^{3} \mathrm{~km}^{2}$ to $46.56 \times 10^{3} \mathrm{~km}^{2}$, most of which $\left(84 \%, 11.99 \mathrm{~km}^{2}\right.$ of total $\left.14.24 \mathrm{~km}^{2}\right)$ was converted from cropland (including irrigated and dryland) owing to prime quality for construction purposes and proximity to the urban area. Nearly $28 \%\left(11.99 \mathrm{~km}^{2}\right.$ of total $\left.42.04 \mathrm{~km}^{2}\right)$ of China's cropland has been lost since 2000 due to urban growth. Croplands have also contributed to substantial percent increases in artificial areas within 251 major cities $\left(83 \%, 7.69 \mathrm{~km}^{2}\right.$ of total $9.21 \mathrm{~km}^{2}$ ) (Figure $7 \mathrm{~b}$ ) and most urban agglomerations, particularly in the Shandong Peninsula $\left(98 \%, 1.02 \mathrm{~km}^{2}\right.$ of total $\left.1.04 \mathrm{~km}^{2}\right)$ (Figure $7 \mathrm{~h}$ ) and the Central Shaanxi Plain $\left(97 \%, 0.33 \mathrm{~km}^{2}\right.$ of total $0.34 \mathrm{~km}^{2}$ ) (Figure 71 ). Furthermore, sizable proportions of growing artificial surfaces have likely been contributed by former wetland in the Pearl River Delta $\left(21 \%, 0.21 \mathrm{~km}^{2}\right.$ of total $\left.1.02 \mathrm{~km}^{2}\right)$ (Figure $\left.7 \mathrm{e}\right)$, the Middle Reaches of the Yangtze River $\left(16 \%, 0.07 \mathrm{~km}^{2}\right.$ of total $\left.0.43 \mathrm{~km}^{2}\right)$ (Figure 7j) and former forest and shrubland in the West Side of the Straits $\left(50 \%, 0.19 \mathrm{~km}^{2}\right.$ of total $0.38 \mathrm{~km}^{2}$ ) (Figure $7 \mathrm{~g}$ ), the Pearl River Delta $\left(22 \%, 0.18 \mathrm{~km}^{2}\right.$ of total $0.81 \mathrm{~km}^{2}$ ) (Figure $\left.7 \mathrm{e}\right)$ and Sichuan-Chongqing $\left(16 \%, 0.10 \mathrm{~km}^{2}\right.$ of total $\left.0.63 \mathrm{~km}^{2}\right)$ (Figure $\left.7 \mathrm{k}\right)$. 


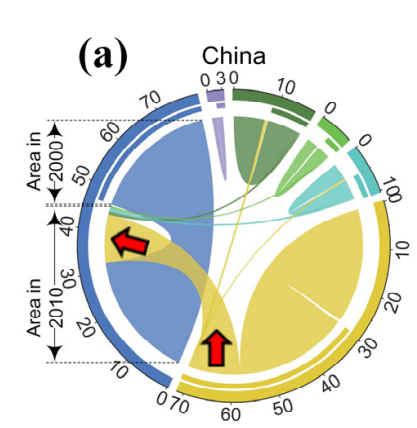

(e) Pearl River Delta

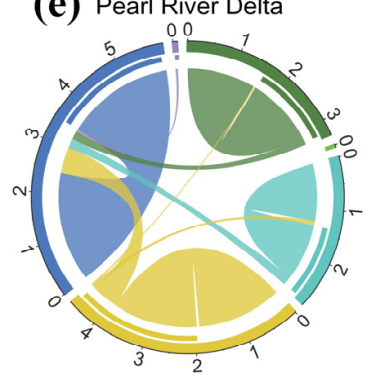

(i) Central Plains

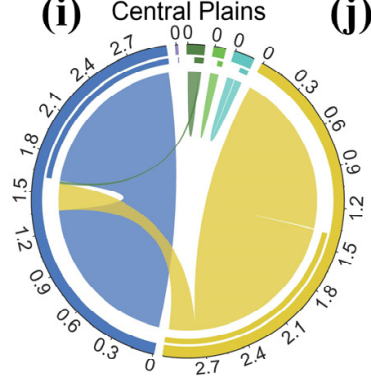

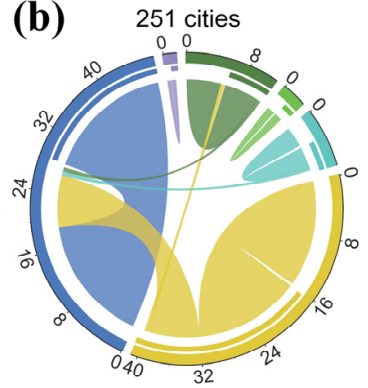

(f)

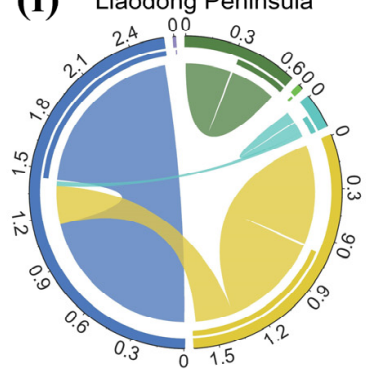

(j)

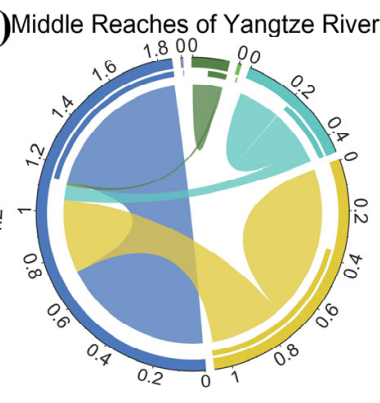

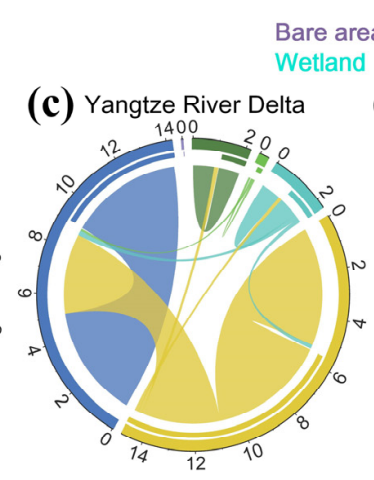

(g) West Side of the Straits (h)

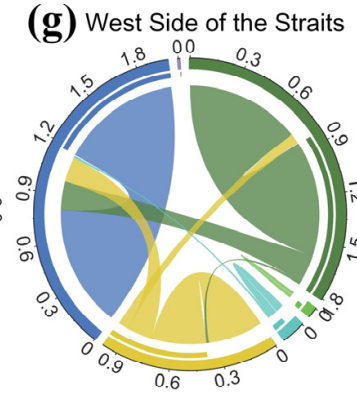

(k) Sichuan-Chongqing

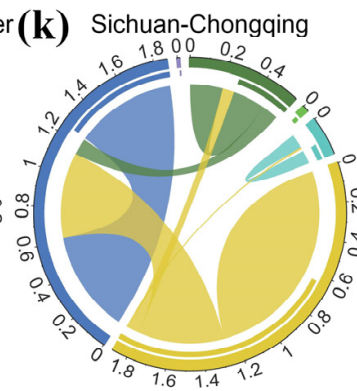

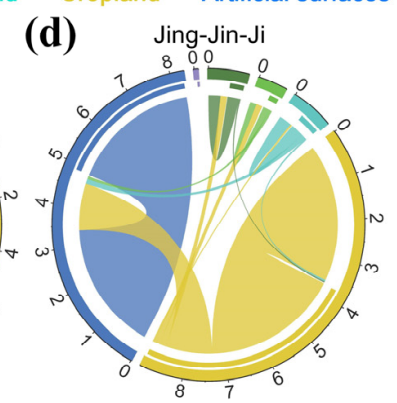

(h) Shandong Peninsula

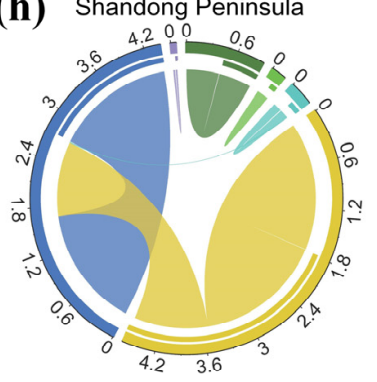

(I) Central Shaanxi Plain

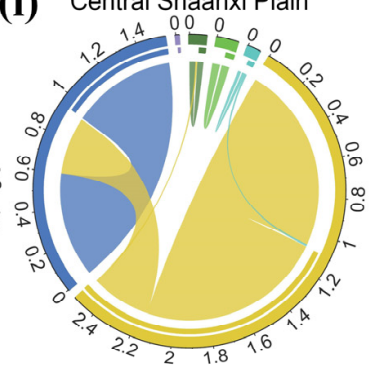

Figure 7. Circular plots of land cover conversion (numbers label the areas of different land types in $103 \mathrm{~km}^{2}$ ) between 2000 and 2010 across urbanizing areas with significant dispersal of urban activities in (a) all cities and towns of China; (b) 251 major cities; and (c-1) 10 largest urban agglomerations. Arrows in (a) illustrate the conversion from cropland to artificial surfaces. Colored text (right-top) labels land types.

\subsection{Prediction of Urban Growth}

Based upon geographic distribution of the velocity of urbanization, we can further explore two major issues for individual cities: (1) how long does it take urban activities similar to those in central urbanized areas before 2000 to cover adjacent urbanizing areas? Additionally; (2) how many intensively urbanized areas will emerge along with urban expansion based on the current velocity? To answer these questions, we calculated spread times and spread areas under the assumption of a ring-shaped expansion of urban growth around the central developed areas (as shown in Figure 8a). Figure $8 b$ exhibits the estimated spread times and spread areas for 16 extra-large ( $>10$ million urban population according to 2010 census data) and large (5-10 million urban population) cities. For those newly urbanizing areas (after 2000), high density urban activities generally require longer spread times to expand across the entire periphery in megacities (45 $\pm 14 \mathrm{yrs}$, mean $\pm 1 \mathrm{sd})$ than those of large cities ( $37 \pm 11$ yrs). Similarly, owing to differences in the size of urbanizing areas and the velocity, the rate of increases in expanding areas substantially varies among cities on the order of 0.35-50.39 $\mathrm{km}^{2} \cdot \mathrm{yr}^{-1}$. Particularly, Shanghai $\left(68 \mathrm{~km}^{2} \cdot \mathrm{yr}^{-1}\right)$ and Suzhou $\left(47 \mathrm{~km}^{2} \cdot \mathrm{yr}^{-1}\right)$ had the fastest increases and Shanghai $\left(3.69 \times 10^{3} \mathrm{~km}^{2}\right)$, Beijing $\left(3.26 \times 10^{3} \mathrm{~km}^{2}\right)$ and Tianjin $\left(2.09 \times 10^{3} \mathrm{~km}^{2}\right)$ showed the most notable expansion of intensively urbanized areas. Furthermore, if the current trend and 
velocity of urbanization holds, sizeable conversions of land use from agricultural and natural lands to human-built features will continuously increase in the next several decades. Our estimates indicate that nearly $13.29 \times 10^{3} \mathrm{~km}^{2}$ of land in China will be converted to artificial surfaces, most likely derived from cropland, while the proportion of human built-up areas in urban regions will increase from a current $52 \%$ (the mean proportion in urbanizing areas of all cities and towns) to $67 \%$ (the average percent in the urbanized areas). This result also indicates an increasing threat to cultivated land reservations due to the preference for cultivated lands during urban land expansions.

(a)

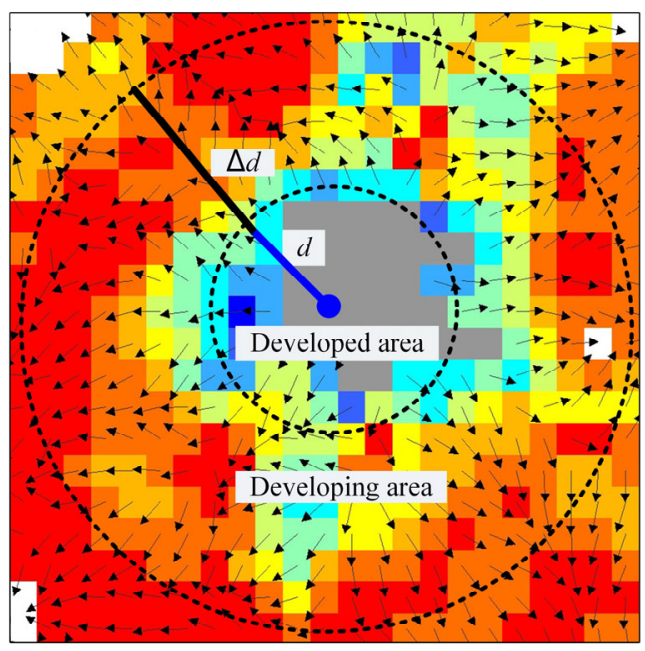

Spread time $=\Delta d /$ velocity

Spread area $=\pi(\Delta d+d)^{2}-\pi d^{2}$ (b)

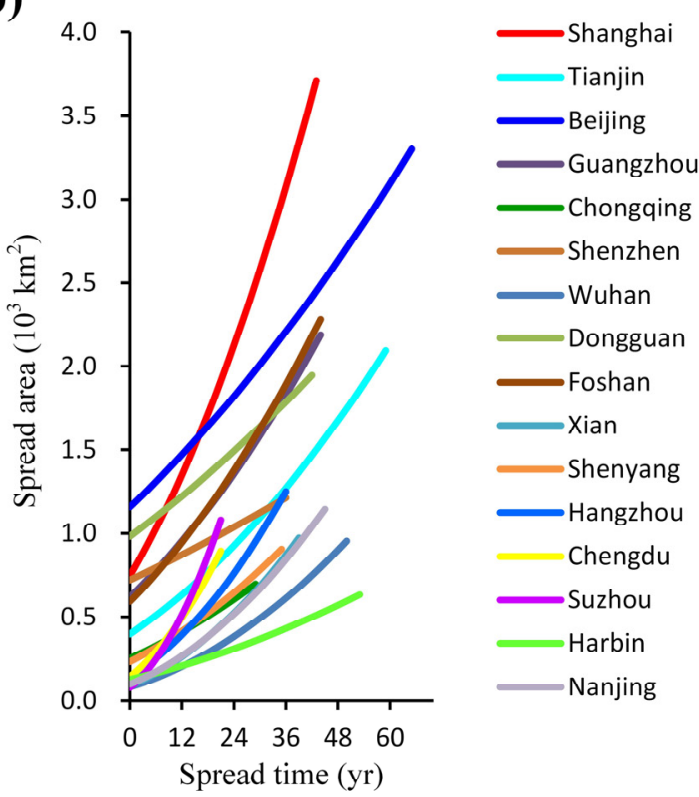

Figure 8. (a) Schematic diagram of the spread time and the spread area. Different colors indicate various speeds of urbanization (see Figure 2d); (b) Estimated spread area versus spread time for 16 extra-large and large cities in China.

\section{Conclusions}

Continuous observations of anthropogenic nighttime light signals, which are closely correlated with population and socioeconomic dynamics in urban areas, provide timely and spatially explicit metrics of urbanization processes. Based upon a time series of satellite-derived nocturnal luminosity data, we developed a new index of the velocity of urbanization through calculating the pixel-level ratio of temporal gradients and spatial gradients of nighttime brightness to investigate the spatial growth of urban activities in China from 2000 to 2010. Our method provides quantitative measures for assessing the speed of urban growth at multiple levels and its variations among urban agglomerations and cities in China over the decade.

Our findings also indicate that the index of the velocity of urbanization encompassing both speed and direction can provide a spatially explicit and consistent measure for studying the expansion of urban areas through estimating how fast they grow and how they geographically expand. Moreover, the combination of the geographic pattern of velocity of urbanization and the pattern of land use change that reveals radially outward expansions of high density urban activities across developing areas and the accompanying emergence of human-built surfaces can further improve our understanding of spatio-temporal dynamics of urban processes and the resulting land cover change. Hence, with the assistance of the velocity of urbanization, we can make projections of future urban expansion and underlying conversions of coupled human and natural landscapes to fully human-dominated urbanscapes. 
In addition, the measured velocity of urbanization could potentially generate estimates and predictions for environmental and ecological responses to aggravated human disturbances during urban expansion. A few but notable observations commonly show geographically explicit consequences of accelerating urban growth in China's cities: for instance, spatially shrinking and fragmentizing lake wetlands within Wuhan [33], gradually disappearing mangrove swamps with the expansion of urban areas to the shoreline in Shenzhen [34], changes in nest features of Magpies along the urban-rural gradient in Hangzhou [35], human settlement density-related fluctuations in baseline hormone levels in Beijing [36], decreased macroinvertebrate richness in stream habitats in relation to urban development level in the Qiantang River [37], and altered surface albedo owing to rapid urbanization [38]. All these observed changes and shifts seem to geographically coincide well with the dispersal of urban activities. Hence, urban planning and management decision-making concerning resource preservation and ecological sustainability should take the spatial rate of urban expansion and subsequent environmental changes into account to meet the challenges of rapid and substantial urbanization progress in present-day China. Further studies on the relationships between the velocity of urbanization and gradients of change in the environment and ecosystems are required in order to expand our knowledge of the urbanization process and its consequences.

Acknowledgments: This study was funded by the National Science Foundation of China (No. 41421001), National Key Basic Research Program of China (No. 2015CB954101); Cultivate Project of Institute of Geographic Sciences and Natural Resources Research, CAS (No. TSYJS03), National Natural Science Foundation of China (No. 41371379) and the Distinguished Young Scholar Program of Institute of Geographic Sciences and Natural Resources Research, CAS (No. 2014RC102). We would like to gratefully thank the anonymous reviewers for their insightful and helpful comments to improve the manuscript.

Author Contributions: Ting Ma and Chenghu Zhou conceived and designed the study and methods. Ting Ma, Zhan Yin, Baoli Li and Susan Haynie collected and processed the data, performed analysis and wrote the paper. Chenghu Zhou contributed to analysis and interpretation of the data.

Conflicts of Interest: The authors declare no conflict of interest.

\section{References}

1. National Bureau of Statistics of China. Tabulation on the 2000 Population Census of the People's Republic of China by County; China Statistical Press: Beijing, China, 2003.

2. National Bureau of Statistics of China. Tabulation on the 2010 Population Census of the People's Republic of China by County; China Statistical Press: Beijing, China, 2013.

3. United Nations, Department of Economic and Social Affairs, Population Division. World Urbanization Prospects: The 2014 Revision, Highlights; United Nations: New York, NY, USA, 2014.

4. Grimm, N.B.; Foster, D.; Groffman, P.; Grove, J.M.; Hopkinsons, C.S.; Nadelhoffer, K.J.; Pataki, D.E.; Peters, D.P.C. The changing landscape: Ecosystem responses to urbanization and pollution across climatic and societal gradients. Front. Ecol. Environ. 2008, 6, 264-272. [CrossRef]

5. Irwin, E.G.; Bockstael, N.E. The evolution of urban sprawl: Evidence of spatial heterogeneity and increasing land fragmentation. Proc. Natl. Acad. Sci. USA 2007, 104, 20672-20677. [CrossRef] [PubMed]

6. Grimm, N.B.; Faeth, S.H.; Golubiewski, N.E.; Redman, C.L.; Wu, J.; Bai, X.; Briggs, J.M. Global change and the ecology of cities. Science 2008, 319, 756-760. [CrossRef] [PubMed]

7. Seto, K.C.; Güneralp, B.; Hutyra, L.R. Global forecasts of urban expansion to 2030 and direct impacts on biodiversity and carbon pools. Proc. Natl. Acad. Sci. USA 2012, 109, 16083-16088. [CrossRef] [PubMed]

8. Cohen, B. Urbanization in developing countries: Current trends, future projections, and key challenges for sustainability. Technol. Soc. 2006, 28, 63-80. [CrossRef]

9. Montgomery, M. The urban transformation of the developing world. Science 2008, 319, 761-764. [CrossRef] [PubMed]

10. Elvidge, C.D.; Baugh, K.E.; Kihn, E.A.; Kroehl, H.W.; Davis, E.R. Mapping city lights with nighttime data from the DMSP Operational Linescan System. Photogramm. Eng. Remote Sens. 1997, 63, 727-734.

11. Doll, C.N.H.; Muller, J.P.; Elvidge, C.D. Night-time imagery as a tool for global mapping of socioeconomic parameters and greenhouse gas emissions. Ambio 2000, 29, 157-162. [CrossRef] 
12. Sutton, P.C. A scale-adjusted measure of "urban sprawl" using nighttime satellite imagery. Remote Sens. Environ. 2003, 86, 353-369. [CrossRef]

13. Small, C.; Pozzi, F.; Elvidge, C.D. Spatial analysis of global urban extent from DMSP-OLS night lights. Remote Sens. Environ. 2005, 96, 277-291. [CrossRef]

14. Sutton, P.; Roberts, D.; Elvidge, C.D.; Baugh, K. Census from heaven: An estimate of the global human population using night-time satellite imagery. Int. J. Remote Sens. 2001, 22, 3061-3076. [CrossRef]

15. Ghosh, T.; Powell, R.L.; Elvidge, C.D.; Baugh, K.E.; Sutton, P.C.; Anderson, S. Shedding light on the global distribution of economic activity. Open Geogr. J. 2010, 3, 148-161.

16. Elvidge, C.D.; Baugh, K.E.; Anderson, S.J.; Sutton, P.C.; Ghosh, T. The Night Light Development Index (NLDI): A spatially explicit measure of human development from satellite. Soc. Geogr. 2012, 7, 23-35. [CrossRef]

17. Small, C.; Elvidge, C.D. Mapping decadal change in anthropogenic night light. Procedia Environ. Sci. 2011, 7 , 353-358. [CrossRef]

18. Small, C.; Elvidge, C.D. Night on earth: Mapping decadal changes of anthropogenic night light in Asia. Int. J. Appl. Earth Obs. Geoinf. 2013, 22, 40-52. [CrossRef]

19. Ma, T.; Zhou, Y.; Zhou, C.; Haynie, S.; Pei, T.; Xu, T. Night-time light derived estimation of spatio-temporal characteristics of urbanization dynamics using DMSPOLS satellite data. Remote Sens. Environ. 2015, 158, 453-464. [CrossRef]

20. Defense Meteorological Satellite Program (DMSP). Available online: http://ngdc.noaa.gov/eog/dmsp.html (accessed on 1 March 2014).

21. Elvidge, C.D.; Hsu, F.C.; Baugh, K.E.; Ghosh, T. National trends in satellite observed lighting: 1992-2012. In Global Urban Monitoring and Assessment through Earth Observation; CRC Press: Boca Raton, FL, USA, 2013; pp. 97-120.

22. Elvidge, C.D.; Ziskin, D.; Baugh, K.E.; Tuttle, B.T.; Ghosh, T.; Pack, D.W.; Erwin, E.H.; Zhizhin, M. A fifteen year record of global natural gas flaring derived from satellite data. Energies 2009, 2, 595-622. [CrossRef]

23. Bennie, J.; Davies, T.W.; Duffy, J.P.; Inger, R.; Gaston, K.J. Contrasting trends in light pollution across Europe based on satellite observed night time lights. Sci. Rep. 2013, 4, 3789. [CrossRef] [PubMed]

24. Zhang, Q.; Schaaf, C.; Seto, K.C. The vegetation adjusted NTL urban index: A new approach to reduce saturation and increase variation in nighttime luminosity. Remote Sens. Environ. 2013, 129, 32-41. [CrossRef]

25. Cleveland, W.S. Robust locally weighted regression and smoothing scatterplots. J. Am. Stat. Assoc. 1979, 74, 829-836. [CrossRef]

26. Loarie, S.R.; Duffy, P.B.; Hamilton, H.; Asner, G.P.; Field, C.B.; Ackerly, D.D. The velocity of climate change. Nature 2009, 462, 1052-1055. [CrossRef] [PubMed]

27. Burrough, P.A.; McDonell, R.A. Principles of Geographical Information Systems; Oxford University Press: New York, NY, USA, 1998.

28. Wu, B.; Yuan, Q.; Yan, C.; Wang, Z.; Yu, X.; Li, A.; Ma, R.; Huang, J.; Cheng, J.; Chang, C.; Liu, C.; Zhang, L.; Li, X.; Zeng, Y.; Bao, A. Land cover changes of China from 2000 to 2010. Quat. Sci. 2014, 34, 723-731.

29. Dobson, J.E.; Bright, E.A.; Coleman, P.R.; Durfee, R.C.; Worley, B.A. LandScan: A global population database for estimating populations at risk. Photogramm. Eng. Remote Sens. 2000, 66, 849-857.

30. Haas, J.; Ban, Y. Urban growth and environmental impacts in Jing-Jin-Ji, the Yangtze River Delta and the Pearl River Delta. Int. J. Appl. Earth Obs. Geoinf. 2014, 30, 42-55. [CrossRef]

31. Lai, H.H. China's western development program: Its rationale, implementation, and prospects. Mod. China 2002, 28, 432-466. [CrossRef]

32. Abel, G.; Sander, N. Quantifying global international migration flows. Science 2014, 343, 1520-1522. [CrossRef] [PubMed]

33. Xu, K.; Kong, C.; Liu, G.; Wu, C.; Deng, H.; Zhang, Y.; Zhuang, Q. Changes of urban wetlands in Wuhan, China, from 1987 to 2005. Prog. Phys. Geogr. 2010, 34, 207-220.

34. Ren, H.; Wu, X.; Ning, T.; Huang, G.; Wang, J.; Jian, S.; Lu, H. Wetland changes and mangrove restoration planning in Shenzhen Bay, Southern China. Landsc. Ecol. Eng. 2011, 7, 241-250. [CrossRef]

35. Wang, Y.; Chen, S.; Jiang, P.; Ding, P. Black-billed magpies (Pica pica) adjust nest characteristics to adapt to urbanization in Hangzhou. Can. J. Zool. 2008, 86, 676-684. [CrossRef]

36. Zhang, S.; Lei, F.; Liu, S.; Li, D.; Chen, C.; Wang, P. Variation in baseline corticosterone levels of tree sparrow (Passer montanus) populations along an urban gradient in Beijing. J. Ornithol. 2011, 152, 801-806. [CrossRef] 
37. Wang, B.; Liu, D.; Liu, S.; Zhang, Y.; Lu, D.; Wang, L. Impacts of urbanization on stream habitats and macroinvertebrate communities in the tributaries of Qiangtang River. Hydrobiologia 2012, 680, 39-51. [CrossRef]

38. Hu, Y.; Jia, G.; Pohl, C.; Zhang, X.; Genderen, J. Assessing surface albedo change and its induced radiation budget under rapid urbanization with Landsat and GLASS data. Theor. Appl. Climatol. 2015, 2. [CrossRef]

(c) 2016 by the authors; licensee MDPI, Basel, Switzerland. This article is an open access article distributed under the terms and conditions of the Creative Commons by Attribution (CC-BY) license (http:/ / creativecommons.org/licenses/by/4.0/). 